\title{
Glycan Profile
}

National Cancer Institute

\section{Source}

National Cancer Institute. Glycan Profile. NCI Thesaurus. Code C128469.

A set of data that both identifies and quantifies all the polysaccharides and the protein or lipid conjug ated polysaccharides in a biological sample or specimen. 